\title{
Seismic operations have variable effects on dive-cycle behavior of bowhead whales in the Beaufort Sea
}

\author{
Frances C. Robertson ${ }^{1,2, *}$, William R. Koski ${ }^{2}$, Tannis A. Thomas ${ }^{2}$, \\ W. John Richardson ${ }^{2}$, Bernd Würsig ${ }^{3}$, Andrew W. Trites ${ }^{1}$ \\ ${ }^{1}$ Department of Zoology and Marine Mammal Research Unit, Fisheries Centre, University of British Columbia, Vancouver, \\ British Columbia V6T 1Z4, Canada \\ ${ }^{2}$ LGL Limited, environmental research associates, King City, Ontario L7B 1A6, Canada \\ ${ }^{3}$ Department of Marine Biology, Texas A\&M University at Galveston, Texas 77553, USA
}

\begin{abstract}
The surfacing, respiration and diving (SRD) behavior of bowhead whales Balaena mysticetus changes upon exposure to seismic operations. However, it is unknown whether these changes differ by season, reproductive status (calves, mothers, and non-calves), and whale activity (traveling, foraging, or socializing). Such SRD behavioral responses to seismic operations might influence the detectability of whales during aerial surveys. We addressed these questions by applying non-parametric univariate tests and linear mixed models to behavioral data collected by aerial observation of bowheads in the Beaufort Sea from 1980 to 2000. Durations of surfacings decreased upon exposure to seismic operations, especially for traveling or socializing non-calf whales. The mixed models also indicated that dive durations were affected by the presence of seismic operations, but the effects depended on other variables such as season and whale activity. Overall, our results suggest that changes in the behavior exhibited by bowhead whales exposed to seismic operations are context-dependent (i.e. responses to seismic operations depend on both the circumstance and activity of the whale). The level of perceived threat may also be important based on similarities with behavioral changes observed in other air-breathing aquatic foragers facing dangers. We conclude that seismic-induced changes in bowhead SRD behaviors may affect the availability of bowhead whales for visual detection in some circumstances. This in turn means that estimates of abundance and distribution of bowhead whales near seismic surveys should be context-sensitive and incorporate correction factors that account for sound exposure, season, reproductive status, and whale activity.
\end{abstract}

KEY WORDS: Bowhead whale $\cdot$ Behavior $\cdot$ Disturbance $\cdot$ Seismic operations $\cdot$ Beaufort Sea $\cdot$ Aerial surveys · Sightability

\section{INTRODUCTION}

Arctic marine systems are experiencing rapid changes in ice coverage and anthropogenic activities. Northern wildlife populations, such as the bowhead whale Balaena mysticetus, may have to contend with growing levels of human activity if human exploitation of natural resources increases and if longer ice-free periods allow new shipping routes to open through Arctic waters (Reeves et al. 2012).
Indigenous people inhabiting this region will also have to continue to adapt to these changes while trying to maintain traditional cultural values and activities. Growing levels of human activity have raised concerns about their potential impacts on the environment and Iñupiat subsistence whaling. Many of these concerns relate to increases in anthropogenic sound in the marine environment, particularly lowfrequency sounds (Richardson et al. 1995a, Southall et al. 2007, Moore et al. 2012). 
The coastal Arctic waters of northern Alaska and northwestern Canada are typically partly or totally free of ice in summer and early autumn (July to October). During that period, bowhead whales of the Bering-Chukchi-Beaufort (BCB) population forage and migrate west, and offshore industrial operators undertake many of their oil and gas exploration activities. During summer, BCB bowhead whales predominantly feed in the Canadian Beaufort Sea and Amundsen Gulf (Würsig et al. 1985, Moore \& Reeves 1993), though whales occasionally congregate off northern Alaska to feed if prey are abundant (Landino et al. 1994). From late August, bowhead whales begin their westward migration, pausing to feed during the early stages of migration through the Alaskan Beaufort Sea when prey are sufficiently dense (Moore et al. 1989, 2010, Richardson \& Thomson 2002). Activities of bowhead whales during summer and autumn are likely influenced by whether local prey abundance is sufficient for efficient foraging.

Behavioral studies of bowhead responses to human activities associated with the oil and gas industry were initiated in the early 1980s (Richardson et al. 1985, 1986, Ljungblad et al. 1988) and showed that some bowhead whales exhibit localized displacement (1.3 to $7.2 \mathrm{~km}$ ) when exposed to industrial sounds. However, subtle changes in surfacing and diving behavior were detectable over larger distances, possibly (at times) as much as $70 \mathrm{~km}$ (Richardson \& Malme 1993). Surfacing and diving behavior has been quantified by measuring how long a whale is visible at or near the surface, the number of times it exhales during a surfacing event, the intervals between successive blows (blow intervals), and the dive duration (Würsig et al. 1984). Brief and shallow submergences between respirations are generally not considered to be dives or interruptions of a surfacing, while the regular series of surfacings and dives are referred to as surface-respiration-dive (SRD) behaviors and are commonly used as indicators of disturbance (Richardson et al. 1986, Ljungblad et al. 1988).

Bowhead whales sometimes change their SRD behavior in the presence of seismic operations andthough results are variable - show a statistically significant tendency to have shorter surfacings, shorter dives, and reduced numbers of blows per surfacing in the presence of noise pulses from seismic operations (Richardson et al. 1986, 1995a, Ljungblad et al. 1988). However, it is not known how the SRD behavior of bowhead whales is affected by the interaction between naturally varying factors and exposure to seismic and other industry operations. Naturally varying factors include region, whale activity, water depth, reproductive status, and time of year, and these factors are known to influence the SRD behaviors of undisturbed bowheads (Würsig et al. 1984, Dorsey et al. 1989, Richardson et al. 1995b).

More recent studies have found that bowhead whales avoid seismic survey vessels during migration but less so while feeding (Richardson et al. 1999, Miller et al. 2005, Koski et al. 2009). They have also shown different reactions to similar sound levels that suggest context-dependent responses - feeding and socializing whales appear more tolerant of potential sources of disturbance than migrating whales (Koski et al. 2009). Behavioral responses of other whale species to human activities could also be similarly context-dependent (Beale \& Monaghan 2004, Ellison et al. 2012). Thus, factors such as activity state, season, and surrounding environment need to be considered when assessing behavioral responses of bowhead whales, particularly when behavioral responses are linked to management decisions.

Changes in SRD behavior that result in whales spending less (or more) time at the surface may bias assessments of distribution and abundance of whales relative to industry operations. These assessments are integral to current management requirements in Alaskan waters because they provide information on numbers of whales that may have been impacted by industry operations. These assessments use sighting data collected by aerial observers, who are only able to record animals at the surface. However, the assessments do not consider how behavioral responses of animals to human activities affect the observers' ability to detect whales. Altered detectability resulting from changes in SRD behavior could lead to under- or over-estimates of the numbers of whales exposed to seismic sounds and to incorrect conclusions about their distribution relative to seismic operations if changes in SRD behavior are large. A clear understanding of how acoustic stimuli affect the distribution of whales is needed to address concerns about the possible impacts that industry activities may have on bowhead whales and Iñupiat subsistence whaling.

The objectives of our study were to determine how sounds from seismic operations affect bowhead SRD behavior and in particular how reproductive status, season, and whale activity influence those variables. Such information is needed to characterize the varying detectability of bowhead whales during aerial surveys and to assess the extent to which seismic operations affect detectability and alter bowhead distribution in Arctic waters. 


\section{MATERIALS AND METHODS}

\section{Data sources and collection}

Bowhead behavior data were collected in the southern Beaufort Sea in summer and autumn during 5 studies conducted from 1980 to 2000 (Fig. 1; see Richardson \& Thomson 2002). These data were collected either during periods when whales had not been recently exposed to potential sources of disturbance (i.e. presumably undisturbed) or during periods when whales were exposed or recently exposed to industrial seismic operations or experimental sources of seismic sounds (potentially disturbed). Consistent with previous related studies, recent exposure to seismic activities was defined as exposure within the previous 30 min (Richardson et al. 1985, 1986, Würsig et al. 1985, Dorsey et al. 1989, Richardson \& Thomson 2002). Bowhead behavior data were collected from fixed-wing aircraft circling

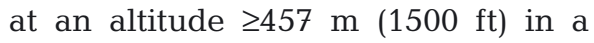
manner that ensured whales were not detectably disturbed by the observation aircraft (Richardson et al. 1985, 1987, Würsig et al. 1985, Richardson \& Thomson 2002; see also Patenaude et al. 2002).

We used standardized procedures for systematically studying and comparing bowhead whale behavior, as described by Würsig et al. (1985) and Richardson et al. (1985). In summary, a behavioral observation session was initiated after a group of whales was detected; focal groups were observed from the circling aircraft for up to $3.5 \mathrm{~h}$. Bowheads with distinctive markings/ scars allowed re-identification of individual whales from one surfacing to the next (either in real time with the aid of binoculars or from later examination of video) and also enabled dive durations to be measured. Fluorescein dye markers were dropped to reference approximate locations of whales during dives. Data concerning a whale's SRD behaviors, other general activities, reproductive status, and environmental variables such as ice presence were recorded in real time onto voice recorders and video cameras. SRD behaviors, summarized in Fig. 2, were defined as follows: dives were defined as sounding dives when the whale submerged out of sight; surfacings were defined as the period when a whale was at the surface or visible just below the surface (Dorsey et al. 1989). For non-calf whales, shallow submergences of $<60 \mathrm{~s}$, occurring between breaths, were defined as serial dives and were not counted as dives or as interruptions of a surfacing (Dorsey et al. 1989). Studies conducted in the early 1980s often did not provide information about the sizes of the whales observed, so data from all non-calf whales (adults without calves and subadults) were combined to investigate effects of seismic operations on bowhead whale behavior.

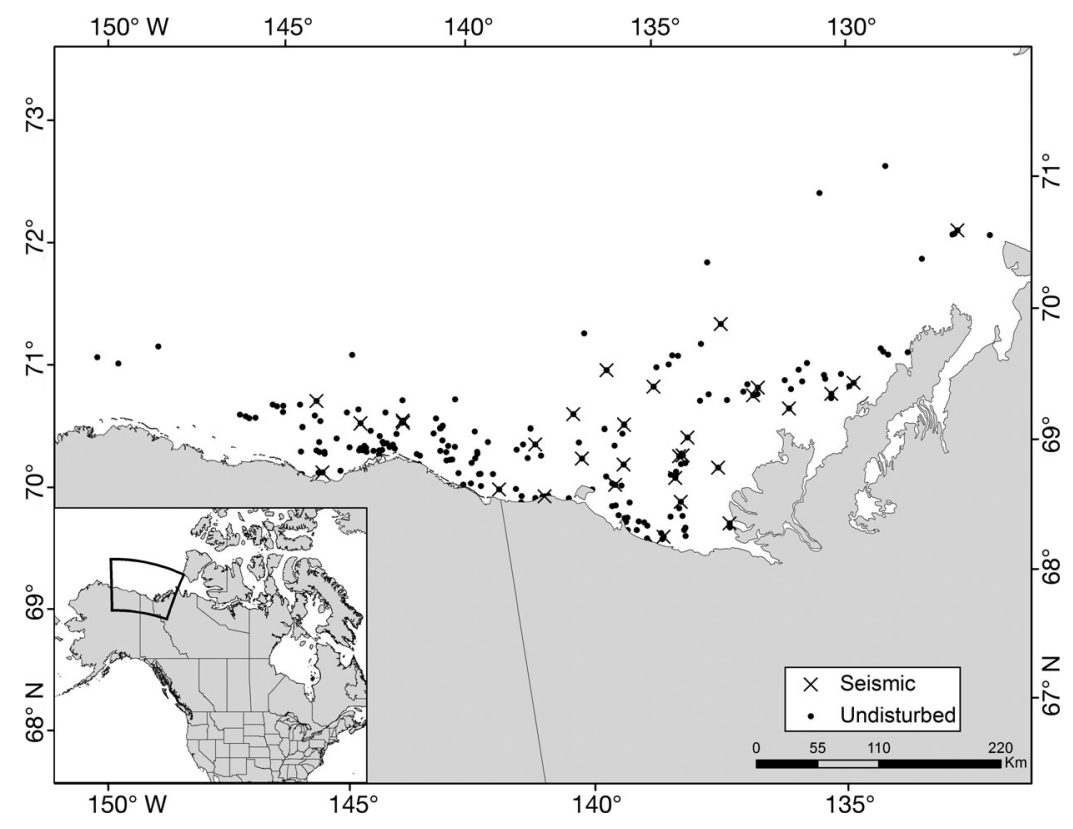

Fig. 1. Locations where behavioral observations of bowhead whales Balaena mysticetus were acquired from 1980 to 2000 while presumably undisturbed $(\bullet)$ and while in the presence of seismic sound $(x)$

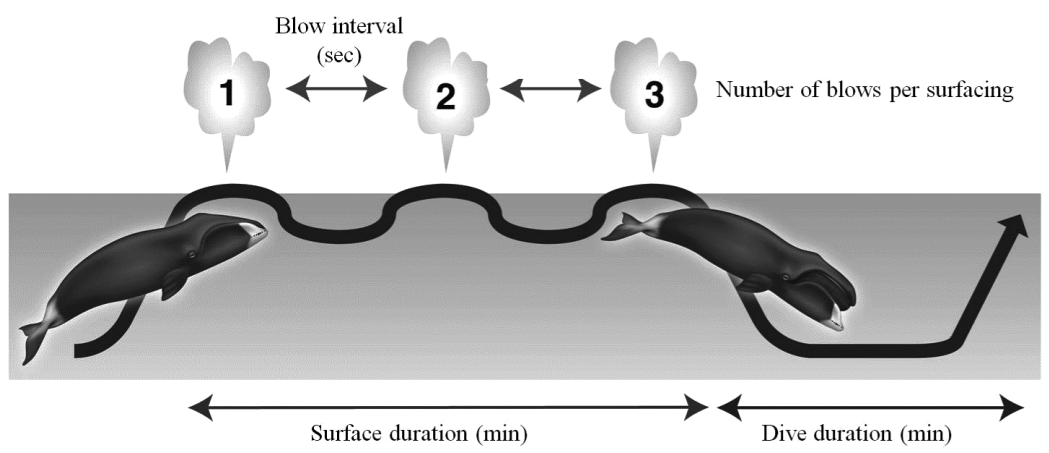

Fig. 2. Key surface-respiration-dive (SRD) behaviors recorded from bowhead whales Balaena mysticetus during aerial-based behavioral observation sessions 
During the 1980 to 1984 bowhead behavior and disturbance study (Richardson et al. 1985, 1986), there were 21 occasions of opportunistic observations when whales were exposed to detectable seismic pulses. The distance of the seismic sources from whales ranged from 6 to $99 \mathrm{~km}$, and the received pulse levels near the whales were determined via sonobuoys, hydrophones, or propagation equations (Richardson et al. 1986). During this period, 4 different seismic vessels and 6 sound source types were used. These included sleeve exploders, open-bottom gas guns, single airguns, and airgun arrays. Pulses received from these source types had similar spectral and temporal characteristics (Greene \& Richardson 1988). Behavioral studies of bowhead whales near a drilling rig in 1986 also allowed for opportunistic observations of bowhead whales exposed to seismic pulses (Koski \& Johnson 1987), and these data were also included in the present study. The variety of different exposure conditions in which behavior data were collected meant there was often only approximate information on received levels of seismic sound, and that limitation precluded incorporating specific data on sound exposure into our analysis.

Observations during experimental exposures to airgun sounds provide an important opportunity to investigate the impact of industry operations on bowhead whale behavior. Systematic behavioral observations (as summarized above) of bowhead whales during 6 experimental exposures were available. During 1980 to 1984,5 such tests were performed using a single $40 \mathrm{in}^{3}$ Bolt air gun (source level $\sim 222 \mathrm{~dB}$ re $1 \mu \mathrm{Pa}-\mathrm{m}_{\mathrm{p}-\mathrm{p}}$ ) deployed 2 to $5 \mathrm{~km}$ from the focal group of whales (Richardson et al. 1986). The pulse characteristics and measured (via sonobuoys) received levels of the airgun sounds near the whales were similar to those $>20 \mathrm{~km}$ from full-scale seismic vessels. Coordination with an operating geophysical vessel also allowed for 1 experiment with a full-scale airgun array. The vessel was directed to pass $1.5 \mathrm{~km}$ to the side of 6 feeding bowhead whales under observation from an aircraft (Richardson et al. 1986). These experiments allowed behavioral observations of whales to be collected before, during, and, where possible, after the whales had been exposed to seismic pulses and were early examples of controlled exposure experiments.

From the SRD observations on focal whales during the aforementioned studies, we created an individual record of each surfacing and dive, and an individual record for the number of blows and median blow interval for each individual surfacing. Sample sizes are shown in Table 1.

\section{Data analysis}

Whales were presumed to be undisturbed when no industrial sounds (e.g. vessel activity, drilling, dredging, seismic sounds, and aircraft $<457 \mathrm{~m}$ above sea level) were detected via sonobuoys deployed during observation sessions or, in the absence of sonobuoy data, when no such activities were present within distances where sounds from these activities were normally detectable underwater. In contrast, whales were considered potentially disturbed by seismic operations when seismic pulses were detected via sonobuoys (Richardson et al. 1985) or when seismic vessels were confirmed to have been operating within distances where they could potentially be heard by whales. On occasion, other anthropogenic activities, most often vessel-related, were also present when seismic sounds were detected. This is expected because seismic operations often include support vessels, e.g. to assist with the maintenance of streamers. These occasions were included in the exposed-to-seismic dataset. Our preliminary analysis showed that the SRD variables of whales in the presence of seismic operations alone did not differ from the SRD variables observed while whales were in the presence of seismic operations plus other anthropogenic activities. With 1 exception, the latter data were subsequently included in the exposed-toseismic category. The 1 instance excluded (1 August 1984) involved an extreme behavioral flight response; it was unclear whether the whale in question reacted to the seismic sounds, the observation aircraft, or both (Richardson et al. 1986).

A post-hoc power analysis via the statistical program $\mathrm{G}^{*}$ Power 3 (Faul et al. 2007) determined that a minimum sample size of 45 observations per treatment was required to minimize the likelihood of Type II errors and detect an actual effect from exposure to seismic sounds at the $\mathrm{p} \leq 0.05$ level. Due to the small sample sizes available, we set a minimum sample size of 15 observations per treatment to maximize the data available in analyses of the effects of seismic

Table 1. Total number of SRD behavior observations available for the Bering-Chukchi-Beaufort bowhead whales while presumably undisturbed and while in the presence of seismic sounds

\begin{tabular}{|lcccc|}
\hline & $\begin{array}{c}\text { Surface } \\
\text { time }\end{array}$ & $\begin{array}{c}\text { Dive } \\
\text { time }\end{array}$ & $\begin{array}{c}\text { No. of blows } \\
\text { per surfacing }\end{array}$ & $\begin{array}{c}\text { Median blow } \\
\text { interval }\end{array}$ \\
\hline Seismic & 586 & 162 & 487 & 836 \\
Undisturbed & 1314 & 538 & 1126 & 2584 \\
\hline
\end{tabular}


operations on whale SRD behavior. However, this only allowed a $40 \%$ chance of detecting an effect from exposure to seismic operations and gave a higher chance of Type II errors.

Blow rate and proportion of time at the surface were calculated for each completely documented SRD cycle (Fig. 2). Blow rate, defined as the number of breaths per minute, is a function of the number of blows per complete surfacing and dive cycle, i.e. dive time plus the subsequent surface time. Blow rate was calculated following the methods of Würsig et al. (1984) and Dorsey et al. (1989). The proportion of time spent at the surface for each SRD cycle was defined as the time at the surface divided by the total duration of the surfacing-dive cycle (dive time plus subsequent surface time). This proportion is important in estimating the fraction of time that whales are potentially sightable during aerial surveys (Davis et al. 1982, Dorsey et al. 1989).

Summary statistics were computed for all SRD behaviors within each category of reproductive status, season, and whale activity (Table 2). Confidence intervals $(95 \%)$ for the mean were computed using a bootstrap technique where each group was re-sampled 10000 times (R package 'boot' v. 1.3.1; Canty \& Ripley 2011).

Distributions for each of the dive-cycle behaviors were highly skewed. As a result, non-parametric Mann-Whitney $U$-tests were used to determine whether SRD variables in the presence of seismic operations differed significantly from those when whales were presumably undisturbed. A correction

Table 2. Reproductive status, group activity, and season categories used to assess the effects of seismic sound on bowhead whale Balaena mysticetus SRD behavior. The effect of seismic operations on non-calf whales was further investigated by season and whale activity state. Foraging was separated into 2 depth categories because previous studies identified water depth as important in explaining differences in SRD behaviors (Würsig et al. 1984, Dorsey et al. 1989)

\begin{tabular}{|c|c|c|}
\hline Factor & Category & Description \\
\hline Exposure state & \multicolumn{2}{|c|}{$\begin{array}{l}\text { Seismic } \\
\text { Presumably undisturbed }\end{array}$} \\
\hline $\begin{array}{l}\text { Reproductive } \\
\text { status }\end{array}$ & $\begin{array}{l}\text { Calf } \\
\text { Mother } \\
\text { Non-calf }\end{array}$ & $\begin{array}{l}<1 \mathrm{yr} \\
\text { Adult whales with a calf } \\
\text { All whales excluding mothers } \\
\text { and calves }\end{array}$ \\
\hline Season & $\begin{array}{l}\text { Summer } \\
\text { Autumn }\end{array}$ & $\begin{array}{l}3-24 \text { August } \\
25 \text { August to } 10 \text { October }\end{array}$ \\
\hline Whale activity & $\begin{array}{l}\text { Travel } \\
\text { Feed-shallow } \\
\text { Feed-deep } \\
\text { Social }\end{array}$ & $\begin{array}{l}\leq 20 \text { m water depth } \\
>20 \text { m water depth }\end{array}$ \\
\hline
\end{tabular}

for multiple hypothesis testing was applied using the false discovery rate approach, following Storey (2002), to avoid inflation in the Type I error rate. This correction was implemented using the R package 'qvalue' (Storey 2002). When the corrected p-values did not indicate a significant effect of seismic operations, post-hoc power tests were used to investigate the likelihood of Type II errors. Kruskal-Wallis nonparametric tests were used to test for significant differences in each SRD behavior among reproductive status or activity categories. These tests were carried out separately for presumably undisturbed and seismic conditions. Where significant differences within groups were detected, post-hoc tests using the Bonferroni corrections were used to determine which categories of whales differed in SRD behavior. However, the results of these non-parametric tests may be overstated because they did not allow for multiple observations from the same whale. Therefore, stated significance levels were considered nominal, and little emphasis was given to differences whose nominal significance levels were $q>0.01$. Despite this, the results of simple univariate tests provided a useful starting point for interpreting how seismic operations and context affected each SRD variable.

\section{Statistical modeling}

We used linear mixed effects (LME) models to characterize the dependence of each bowhead SRD variable on environmental and whale-related variables. As a first step, we examined the SRD data using exploratory dataanalysis tools within the statistical analysis program $\mathrm{R}$ to identify key issues that may affect the overall fit of each model. All observations from calves were removed from the data because their SRD cycles were significantly different from those of other whales (Richardson \& Thomson 2002). This left the observations collected from non-calf whales and mothers. Outliers were identified with Cleveland dot plots and pair plots in combination with Pearson's correlation coefficients. Variance-inflation-factor (VIF) values were used to identify the presence of collinearity between explanatory variables. Only water depth and distance from shore were possibly collinear $(\mathrm{VIF}=0.6)$; depth was 
retained in the analysis, and distance from shore was dropped to avoid multicollinearity and minimize model performance issues (Zuur et al. 2010). We excluded SRD records in which values of $\geq 1$ explanatory variables were unknown.

Ten variables were hypothesized to be potential predictors of SRD cycle parameters (Table 3). The number of whales within $1 \mathrm{~km}$ of the focal animal (N.1KM) was log-transformed to obtain an even spread of values. All other explanatory variables were factorial and were divided into levels (Table 3). Whale identification (ID) numbers were assigned when the data were coded, with a new ID number being assigned when it was uncertain whether a whale had been seen earlier in the observation session. In this analysis, whales with different ID numbers were treated as unique, though some had presumably been seen before.
Before analysis, SRD variables were transformed to reduce skewness in their distributions. Dive duration, median blow interval, and number of blows per surfacing were log-transformed, while surface duration was square-root-transformed. Transformed data for each SRD variable were individually modeled as a function of environmental and whalerelated variables, including a variable describing the presence of seismic operations, using LME models. Only 2-way interaction terms for which the effect of seismic operations may have been dependent on another variable were included in the model. This allowed us to investigate whether (1) the presence of seismic operations had a significant effect on each behavior and (2) if the effect of seismic operations depended on other environmental or whale-related variables. Variation resulting from multiple observations of individual whales (when

Table 3. Environmental and bowhead whale-related variables included in the linear mixed effects models. -: category was not included in the model

\begin{tabular}{|c|c|c|c|c|c|}
\hline Explanatory variable & Scale & $\begin{array}{l}\text { Number of } \\
\text { blows }\end{array}$ & $\begin{array}{c}\text { Median } \\
\text { blow interval }\end{array}$ & $\begin{array}{l}\text { Surface } \\
\text { time }\end{array}$ & $\begin{array}{l}\text { Dive } \\
\text { time }\end{array}$ \\
\hline \multicolumn{6}{|l|}{ Environmental variables } \\
\hline \multirow[t]{2}{*}{ Season } & Autumn ${ }^{\mathrm{a}}$ & $\mathrm{x}$ & $\mathrm{X}$ & $\mathrm{X}$ & $\mathrm{X}$ \\
\hline & Summer & $\mathrm{X}$ & $\mathrm{X}$ & $\mathrm{X}$ & $\mathrm{X}$ \\
\hline \multirow[t]{5}{*}{ Water depth } & $<10 \mathrm{~m}^{\mathrm{a}}$ & $\mathrm{x}$ & $\mathrm{X}$ & $\mathrm{X}$ & $\mathrm{X}$ \\
\hline & $10-19 \mathrm{~m}$ & $\mathrm{X}$ & $\mathrm{X}$ & $\mathrm{x}$ & $\mathrm{X}$ \\
\hline & $20-49 \mathrm{~m}$ & $\mathrm{x}$ & $\mathrm{X}$ & $\mathrm{X}$ & $\mathrm{X}$ \\
\hline & $50-199 \mathrm{~m}$ & $\mathrm{x}$ & $\mathrm{X}$ & $\mathrm{X}$ & $\mathrm{X}$ \\
\hline & $>200 \mathrm{~m}$ & $\mathrm{x}$ & $\mathrm{X}$ & $\mathrm{X}$ & $\mathrm{X}$ \\
\hline \multirow[t]{2}{*}{ Ice $\%$} & $\leq 5 \%$ ice $^{\mathrm{a}}$ & $\mathrm{x}$ & $\mathrm{X}$ & $\mathrm{X}$ & $\mathrm{X}$ \\
\hline & $>5 \%$ ice & $\mathrm{x}$ & $\mathrm{X}$ & $\mathrm{X}$ & $\mathrm{X}$ \\
\hline \multirow[t]{2}{*}{ Seismic sound } & Presumably undisturbed ${ }^{a}$ & $\mathrm{x}$ & $\mathrm{x}$ & $\mathrm{X}$ & $\mathrm{X}$ \\
\hline & Seismic present & $\mathrm{x}$ & $\mathrm{x}$ & $\mathrm{x}$ & $\mathrm{x}$ \\
\hline \multicolumn{6}{|l|}{ Whale variables } \\
\hline \multirow[t]{3}{*}{ Group activity state } & Feeding (all depths) ${ }^{\mathrm{a}}$ & $\mathrm{X}$ & $\mathrm{X}$ & $\mathrm{X}$ & $\mathrm{X}$ \\
\hline & Travel & $\mathrm{x}$ & $\mathrm{X}$ & $\mathrm{X}$ & $\mathrm{X}$ \\
\hline & Social & $\mathrm{X}$ & $\mathrm{X}$ & $\mathrm{X}$ & $\mathrm{X}$ \\
\hline \multirow[t]{5}{*}{ Motion } & No motion/milling ${ }^{\mathrm{a}}$ & $\mathrm{X}$ & $\mathrm{X}$ & $\mathrm{X}$ & - \\
\hline & Slow & $\mathrm{x}$ & $\mathrm{x}$ & $\mathrm{X}$ & - \\
\hline & Moderate & $\mathrm{x}$ & $\mathrm{X}$ & $\mathrm{x}$ & - \\
\hline & Fast & $\mathrm{x}$ & $\mathrm{X}$ & $\mathrm{X}$ & - \\
\hline & Changing & $\mathrm{x}$ & $\mathrm{X}$ & - & - \\
\hline \multirow[t]{2}{*}{ Reproductive status } & Non-calfa & $\mathrm{x}$ & $\mathrm{X}$ & $\mathrm{x}$ & $\mathrm{X}$ \\
\hline & Mother & $\mathrm{X}$ & $\mathrm{X}$ & $\mathrm{X}$ & $\mathrm{X}$ \\
\hline \multirow[t]{3}{*}{ Group size } & 1 whale $^{\mathrm{a}}$ & $\mathrm{X}$ & $\mathrm{X}$ & $\mathrm{X}$ & $\mathrm{X}$ \\
\hline & $2-3$ whales & $\mathrm{X}$ & $\mathrm{X}$ & $\mathrm{X}$ & $\mathrm{X}$ \\
\hline & $\geq 4$ whales & $\mathrm{x}$ & $\mathrm{x}$ & $\mathrm{x}$ & $\mathrm{X}$ \\
\hline No. of whales within $1 \mathrm{~km}$ & $\log (\mathrm{N} .1 \mathrm{KM})$ & $\mathrm{x}$ & $\mathrm{x}$ & $\mathrm{x}$ & $\mathrm{X}$ \\
\hline \multirow[t]{2}{*}{ Aerial behavior } & No aerial behavior observed ${ }^{a}$ & - & $\mathrm{x}$ & $\mathrm{x}$ & - \\
\hline & Aerial behavior observed & - & $\mathrm{x}$ & $\mathrm{x}$ & - \\
\hline
\end{tabular}


recognized) was included as a random effect in each model.

LME models were fitted using the R package 'nlme' v.3.1-101 (Pinheiro et al. 2011), using restricted maximum likelihood (REML) estimation. Model selection followed a backward stepwise methodology, as recommended by Diggle et al. (2002) and Zuur et al. (2009), using a combination of likelihood-ratio tests and AIC. The selected models were validated through graphical examination of the normalized residuals and assessed for the presence of homogeneity as well as the presence of spatial and temporal correlation. When the presence of temporal autocorrelation was identified in a model, an autoregressive (AR-1) correlation structure was included (Zuur et al. 2009).

The effects of explanatory variables and interaction terms were deemed significant if the $95 \%$ confidence intervals of the parameter estimates did not overlap zero (Johnson 1999). The goodness of fit for each model was assessed through the calculation of the $\mathrm{R}^{2}$ coefficients (Vonesh et al. 1996, Kramer 2005, Liu et al. 2008). $R^{2}$ statistics based on the likelihood ratio $R_{L R}^{2}$ were calculated using functions available from the R package 'Immfit' v.1.0 (Maj 2011).

A retrospective sensitivity analysis was performed to investigate the robustness of each optimal model. Each model was fitted to successively smaller cohorts of behavior data, in which every model in turn had 1 yr of data removed. $\mathrm{R}^{2}$ statistics based on likelihood ratio $\mathrm{R}_{\mathrm{LR}}^{2}$ were calculated, and model results were compared graphically to assist interpretation of model robustness and identify evidence of retrospective bias in each behavior model.

\section{RESULTS}

The 4 measurable variables that make up the SRD cycle of a bowhead whale (number of blows per surfacing, median blow interval, surface duration, and dive duration) varied with reproductive states, activities, and seasons. They also revealed behavioral changes associated with the presence of seismic operations (Tables 4a, 4b, \& 4c).

In general, mothers had the longest mean SRD cycle (13.0 min total surface plus dive time in presumably undisturbed conditions), and calves had the shortest (4.7 min), while non-calves (i.e. all adult and subadult whales excluding mothers and calves) fell in between (9.6 min). However, SRD cycle times varied with season and activity state. Most notably, SRD cycles were shortest for socializing whales and for those feeding in shallow waters and were longest for traveling whales (lasting an average of $13.3 \mathrm{~min})$.

Table 4a. Summary statistics by whale reproductive status for each surface-dive variable of bowhead whales under both 'presumably undisturbed' and 'seismic' categories. Corrected nominally significant differences at the $q \leq 0.01$ level between 'seismic' and 'presumably undisturbed' are in bold. Corrections have been based on the false discovery rate method for multiple hypothesis testing. The significance levels of differences among whale status groups are shown by the p-values

\begin{tabular}{|c|c|c|c|c|c|c|c|c|c|c|}
\hline \multirow[t]{2}{*}{ Surface-dive behavior } & \multicolumn{3}{|c|}{$\longrightarrow$ Non-calf $\longrightarrow$} & \multicolumn{3}{|c|}{$\longrightarrow$ Mother $\longrightarrow$} & \multicolumn{3}{|c|}{$\longrightarrow$ Calf $\longrightarrow$} & \multirow{2}{*}{$\begin{array}{c}\text { Differences among } \\
\text { reproductive states } \\
\text { p-value }\end{array}$} \\
\hline & $\mathrm{n}$ & $\overline{\mathrm{X}}$ & $\mathrm{SD}$ & $\mathrm{n}$ & $\overline{\mathrm{X}}$ & $\mathrm{SD}$ & $\mathrm{n}$ & $\overline{\mathrm{X}}$ & $\mathrm{SD}$ & \\
\hline \multicolumn{11}{|l|}{ Number of blows } \\
\hline Presumably undisturbed & 911 & 5.22 & 3.44 & 67 & 6.21 & 3.51 & 148 & 3.94 & 3.81 & $<0.001$ \\
\hline Seismic & 417 & 3.96 & 3.12 & 26 & 5.62 & 4.23 & 44 & 3.36 & 2.67 & 0.060 \\
\hline \multicolumn{11}{|l|}{ Median blow interval (s) } \\
\hline Presumably undisturbed & 2252 & 13.55 & 7.08 & 147 & 17.32 & 5.35 & 185 & 13.48 & 7.53 & $<0.001$ \\
\hline Seismic & 744 & 14.25 & 6.96 & 43 & 17.55 & 7.16 & 49 & 16.06 & 9.71 & $<0.001$ \\
\hline \multicolumn{11}{|l|}{ Surface time (min) } \\
\hline Presumably undisturbed & 1070 & 1.23 & 0.90 & 80 & 2.03 & 1.14 & 164 & 0.93 & 1.09 & $<0.001$ \\
\hline Seismic & 504 & 1.02 & 0.77 & 29 & 1.61 & 1.40 & 53 & 0.92 & 1.10 & 0.003 \\
\hline \multicolumn{11}{|l|}{ Dive time (min) } \\
\hline Presumably undisturbed & 333 & 8.41 & 7.16 & 67 & 10.95 & 6.37 & 138 & 3.75 & 4.90 & $<0.001$ \\
\hline Seismic & 106 & 8.81 & 8.47 & 18 & 12.34 & 8.89 & 38 & 3.82 & 4.44 & $<0.001$ \\
\hline \multicolumn{11}{|l|}{ Proportion of time at surface } \\
\hline Presumably undisturbed & 292 & 0.175 & 0.135 & 60 & 0.198 & 0.128 & 129 & 0.255 & 0.189 & $<0.001$ \\
\hline Seismic & 96 & 0.171 & 0.147 & 16 & 0.144 & 0.118 & 36 & 0.221 & 0.233 & 0.718 \\
\hline \multicolumn{11}{|l|}{ Blow rate (per min) } \\
\hline Presumably undisturbed & 256 & 0.755 & 0.471 & 52 & 0.640 & 0.426 & 121 & 2.087 & 2.513 & $<0.001$ \\
\hline Seismic & 76 & 0.817 & 0.605 & 15 & 0.581 & 0.369 & 32 & 1.694 & 1.098 & $<0.001$ \\
\hline
\end{tabular}


Table $4 \mathrm{~b}$. Summary statistics by season for each surface-dive variable for non-calf bowhead whales under both 'presumably undisturbed' and 'seismic' categories. Corrected nominally significant differences at the $\mathrm{q} \leq 0.01$ level between 'seismic' and 'presumably undisturbed' groups are in bold. Corrections have been based on the false discovery rate method for multiple hypothesis testing. The significance levels of differences between seasons are shown by the p-values

\begin{tabular}{|c|c|c|c|c|c|c|c|}
\hline \multirow[t]{2}{*}{ Surface-dive behavior } & \multicolumn{3}{|c|}{ - Summer - } & \multicolumn{3}{|c|}{ - Autumn- } & \multirow{2}{*}{$\begin{array}{c}\text { Differences } \\
\text { between seasons } \\
\text { p-value }\end{array}$} \\
\hline & $\mathrm{n}$ & $\overline{\mathrm{X}}$ & $\mathrm{SD}$ & $\mathrm{n}$ & $\overline{\mathrm{X}}$ & $\mathrm{SD}$ & \\
\hline \multicolumn{8}{|l|}{ Number of blows } \\
\hline Presumably undisturbed & 370 & 4.39 & 3.07 & 541 & 5.79 & 3.57 & $<0.001$ \\
\hline Seismic & 234 & 3.55 & 2.65 & 183 & 4.50 & 3.56 & 0.046 \\
\hline \multicolumn{8}{|l|}{ Median blow interval (s) } \\
\hline Presumably undisturbed & 851 & 13.60 & 8.48 & 1401 & 13.52 & 6.08 & 0.155 \\
\hline Seismic & 378 & 14.06 & 6.83 & 366 & 14.45 & 7.09 & 0.348 \\
\hline \multicolumn{8}{|l|}{ Surface time (min) } \\
\hline Presumably undisturbed & 414 & 1.11 & 0.78 & 656 & 1.31 & 0.97 & $<0.001$ \\
\hline Seismic & 281 & 0.94 & 0.65 & 223 & 1.12 & 0.89 & 0.067 \\
\hline \multicolumn{8}{|l|}{ Dive time (min) } \\
\hline Presumably undisturbed & 84 & 6.57 & 5.91 & 249 & 9.03 & 7.45 & $<0.001$ \\
\hline Seismic & 71 & 6.18 & 5.37 & 35 & 14.14 & 10.90 & 0.002 \\
\hline \multicolumn{8}{|l|}{ Proportion of time at surface } \\
\hline Presumably undisturbed & 75 & 0.169 & 0.116 & 217 & 0.177 & 0.141 & 0.918 \\
\hline Seismic & 67 & 0.191 & 0.159 & 29 & 0.124 & 0.103 & 0.096 \\
\hline \multicolumn{8}{|l|}{ Blow rate (per min) } \\
\hline Presumably undisturbed & 70 & 0.830 & 0.492 & 186 & 0.727 & 0.461 & 0.066 \\
\hline Seismic & 55 & 0.880 & 0.657 & 21 & 0.653 & 0.413 & 0.193 \\
\hline
\end{tabular}

Table 4c. Summary statistics by activity state for each surface-dive for non-calf bowhead whales under both 'presumably undisturbed' and 'seismic' categories. Corrected nominally significant differences at the $q \leq 0.01$ level between 'seismic' and 'presumably undisturbed' are in bold. Corrections have been based on the false discovery rate method for multiple hypothesis testing. The significance levels of differences among activity states are shown by the p-values

\begin{tabular}{|c|c|c|c|c|c|c|c|c|c|c|c|c|c|}
\hline \multirow{2}{*}{ Surface-dive behavior } & \multirow{2}{*}{$\mathrm{n}$} & \multicolumn{2}{|c|}{ - Travel } & \multicolumn{3}{|c|}{ - Social } & \multicolumn{3}{|c|}{ Feed shallow } & \multicolumn{3}{|c|}{ Feed deep } & \multirow{2}{*}{$\begin{array}{c}\text { Differences } \\
\text { among } \\
\text { activity states } \\
\text { p-value }\end{array}$} \\
\hline & & $\overline{\mathrm{X}}$ & $\mathrm{SD}$ & $\mathrm{n}$ & $\overline{\mathrm{X}}$ & $\mathrm{SD}$ & $\mathrm{n}$ & $\overline{\mathrm{X}}$ & $\mathrm{SD}$ & $\mathrm{n}$ & $\overline{\mathrm{X}}$ & $\mathrm{SD}$ & \\
\hline \multicolumn{14}{|l|}{ Number of blows } \\
\hline Presumably undisturbed & 110 & 6.15 & 3.41 & 299 & 5.15 & 3.40 & 205 & 5.05 & 3.22 & 194 & 4.87 & 3.37 & 0.003 \\
\hline Seismic & 66 & 3.61 & 2.80 & 268 & 3.72 & 3.12 & 39 & 4.85 & 2.84 & 30 & 5.30 & 3.81 & 0.007 \\
\hline \multicolumn{14}{|l|}{ Median blow interval (s) } \\
\hline Presumably undisturbed & 206 & 16.59 & 6.84 & 765 & 13.10 & 5.95 & 503 & 12.99 & 6.43 & 549 & 12.79 & 6.43 & $<0.001$ \\
\hline Seismic & 63 & 15.32 & 7.93 & 469 & 14.57 & 6.98 & 99 & 11.89 & 4.29 & 88 & 14.75 & 8.36 & $<0.001$ \\
\hline \multicolumn{14}{|l|}{ Surface time (min) } \\
\hline Presumably undisturbed & 120 & 1.51 & 0.92 & 369 & 1.23 & 0.76 & 258 & 1.16 & 1.14 & 213 & 1.11 & 0.71 & $<0.001$ \\
\hline Seismic & 79 & 0.88 & 0.78 & 326 & 1.04 & 0.79 & 46 & 0.93 & 0.51 & 38 & 1.21 & 0.83 & 0.100 \\
\hline \multicolumn{14}{|l|}{ Dive time (min) } \\
\hline Presumably undisturbed & 77 & 11.76 & 8.20 & 66 & 5.44 & 4.47 & 97 & 6.22 & 5.30 & 47 & 8.74 & 6.31 & $<0.001$ \\
\hline Seismic & 18 & 10.76 & 11.29 & 44 & 8.45 & 8.73 & 21 & 6.81 & 5.75 & 20 & 10.66 & 7.69 & 0.476 \\
\hline \multicolumn{14}{|l|}{ Proportion of time at surface } \\
\hline Presumably undisturbed & 70 & 0.16 & 0.13 & 58 & 0.18 & 0.11 & 91 & 0.20 & 0.16 & 42 & 0.15 & 0.10 & 0.263 \\
\hline Seismic & 14 & 0.15 & 0.13 & 42 & 0.20 & 0.15 & 20 & 0.15 & 0.12 & 17 & 0.13 & 0.16 & 0.051 \\
\hline \multicolumn{14}{|l|}{ Blow rate (per min) } \\
\hline Presumably undisturbed & 61 & 0.627 & 0.479 & 55 & 0.829 & 0.415 & 74 & 0.803 & 0.543 & 39 & 0.702 & 0.402 & 0.005 \\
\hline Seismic & 8 & 0.838 & 0.522 & 33 & 0.872 & 0.602 & 17 & 0.666 & 0.301 & 15 & 0.695 & 0.532 & 0.388 \\
\hline
\end{tabular}

SRD behaviors also varied in the presence of seismic operations. In some circumstances, the presence of seismic operations was associated with whales exhibiting mean surface durations shorter, to a nom- inally significant extent, than those without seismic operations. This is best understood by a closer examination of the individual effects of seismic sound on each dive-cycle behavior. 


\section{Number of blows per surfacing}

The average number of blows per surfacing was lower in the presence of seismic operations, but the difference was nominally significant only among non-calf whales (for which the mean was $24 \%$ lower with seismic operations; Table 4a). This effect was consistent between seasons, although the average number of blows was lower in summer than in autumn (Fig. 3, Table $4 \mathrm{~b}$ ). The apparent effects of seismic operations were most notable for traveling non-calf whales (Fig. 3, Table 4c). Overall, the average number of blows per surfacing varied between seasons and among activity states in both the presence and absence of seismic operations.

When the various factors hypothesized to be related to SRD behavior were considered simultaneously, the number of blows per surfacing was significantly related to 5 variables and 2 interaction terms (Table 5a). However, this best-fitting LME model could only explain $13 \%$ of the observed variation in the number of blows. The number of blows per surfacing was related to interactions of seismic with the activity state (Fig. 4) and the number of whales within $1 \mathrm{~km}$. The LME model further suggests that number of blows per surfacing was related to the season, water depth, ice coverage, and whale motion (Table 5a).

\section{Blow intervals}

The presence of seismic operations had no observable effect on median blow intervals of bowhead whales categorized by season or by whale reproductive status (Tables 4a \& 4b). However, median blow intervals of non-calf bowheads categorized by whale activity showed some nominally significant differences (Fig. 3, Table 4c). In the presence of seismic, the median blow intervals of whales foraging in shallow waters differed significantly from those of both traveling and socializing whales (Mann-Whitney $U$ tests; travel, $\mathrm{p}=0.035$; social, $\mathrm{p}<0.001$ ).

Based on the LME model, the median blow interval was a function of 7 variables and 4 interaction terms
(Table 5b). However, this best-fitting LME model could only explain $14 \%$ of the observed variation in median blow intervals of bowhead whales. Median blow interval was related to interactions of seismic with the season, water depth, whale activity, and aerial behavior (Fig. 4, Table 5b). After allowance for the numerous interaction effects, the median blow interval also appeared to depend on the presence of seismic and several other variables (Table $5 b$ ).

\section{Surface durations}

In the presence of seismic operations, the average surface duration for non-calf whales was lower, by a nominally significant amount, than that of presumably undisturbed bowheads (Table 4a, Fig. 3). This was evident in both summer and autumn and for both traveling and socializing non-calf whales (Tables $4 \mathrm{~b}$ \& 4c, Fig. 3). Traveling whales exhibited a mean surfacing duration that was $41 \%$ shorter in the presence 


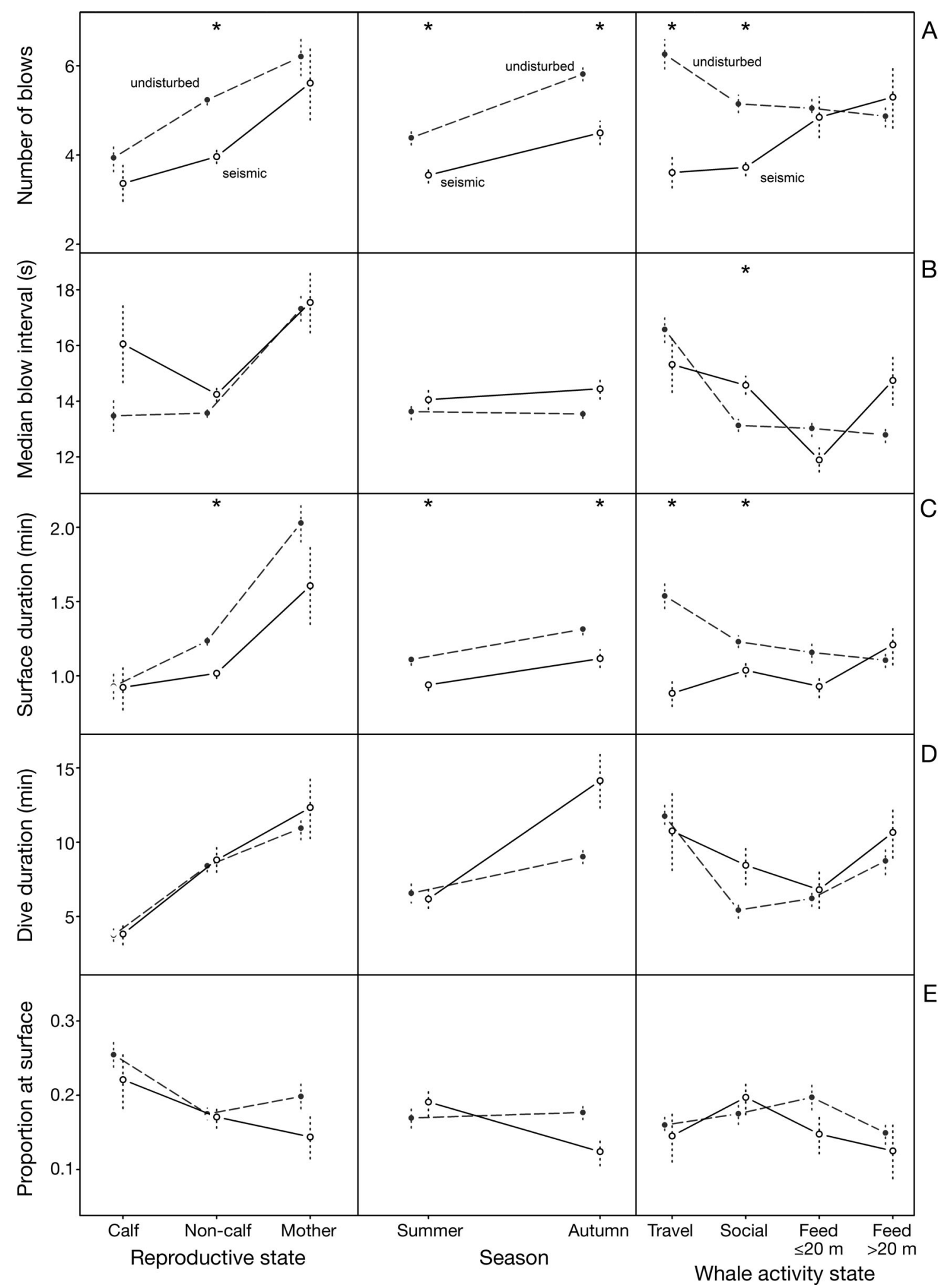

Fig. 3. Mean SRD behaviors of bowhead whales Balaena mysticetus by reproductive state, season, and whale activity while in the presence $(O)$ or absence $(0)$ of seismic sounds. SRD behaviors $( \pm 95 \% \mathrm{CI})$ include $(\mathrm{A})$ number of blows per surfacing, (B) median blow interval, (C) duration of surfacing, (D) duration of dive, and (E) proportion of time spent on the surface during a surfacing-dive cycle. *Significant differences in behavior between seismic and presumably undisturbed conditions (q $<0.01$, corrected Wilcoxon rank-based tests) 
of seismic sounds (Fig. 3). Also, mean surface durations depended on reproductive status: both with and without seismic operations, calves had short surface times and mothers had long surface times relative to other bowhead whales (Table 4a, Fig. 3).

Surface duration was a function of 7 variables and 2 interaction terms (Table $5 \mathrm{c}$ ), and this best-fitting LME model explained $24 \%$ of the variation in the observed surface durations (Table 5c). Surface duration was related to interactions of seismic with whale activity (Fig. 4) and the number of whales within $1 \mathrm{~km}$. After allowance for interaction effects, the surface duration also appeared to depend on season, whale motion, reproductive status, ice cover, and water depth (Table 5c).

\section{Dive durations}

Exposure to seismic operations had no significant effect on the average dive duration of mothers, noncalves, or calves (Table 4a). Similarly, there was no apparent association between the presence of seismic operations and the average dive times of non-calf whales observed in different seasons or engaged in different activities (Tables $4 \mathrm{~b} \& 4 \mathrm{c}$ ). The mean dive times of non-calf whales were longer in the autumn than during the summer regardless of the presence of seismic operations (Mann Whitney $U$-tests: presumably undisturbed, $\mathrm{p}<0.001$; seismic, $\mathrm{p}=0.002$ ).

The best-fitting LME model showed that dive duration was a function of 6 variables and 3 interaction terms (Table $5 \mathrm{~d}$ ) and explained $39 \%$ of the variation in the observed dive durations. Dive duration depended on the interactions of seismic with season, number of whales within $1 \mathrm{~km}$, and whale activity (Fig. 4). The LME model identified effects of seismic operations on dive duration that were not evident from the univariate comparisons. After allowance for interaction effects, it was evident that dive duration also depended on water depth, ice percentage, reproductive status, and group size (Table $5 \mathrm{~d}$ ).

\section{Blow rate and the proportion of time at the surface}

Blow rate is a function of number of blows per surfacing, surface duration, and dive duration, each of which (at times) appeared to be affected by the presence of seismic operations (see above). Blow rates apparently differed with whale reproductive status and whale activity (Tables 4a \& 4c). However, the presence of seismic operations did not significantly affect the average blow rates of bowhead whales for

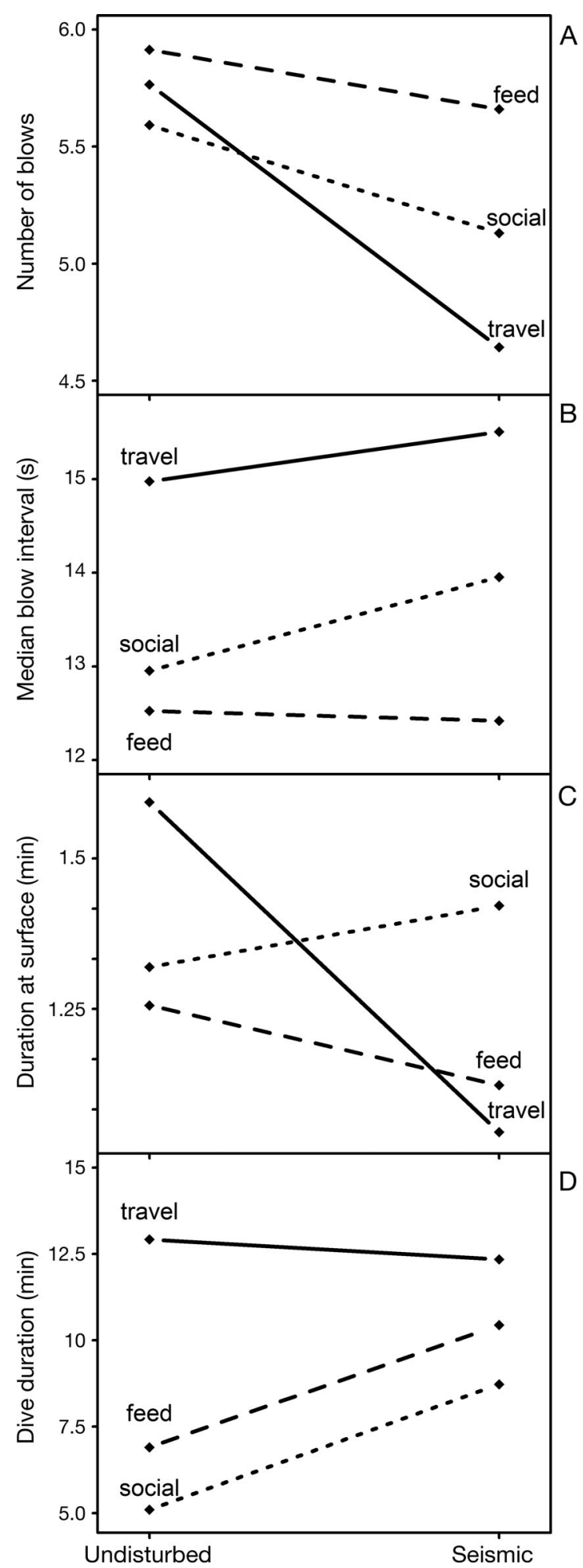

Fig. 4. The interaction between the LME model factors of activity state and sound exposure (presumably undisturbed vs. exposed to seismic operations) for each SRD behavior of bowhead whales: (A) median number of blows per surfacing, (B) median time between breaths, (C) duration of surfacing, and (D) dive duration 
Table 5b. Linear mixed effects model for the median blow interval for bowhead whales. A log transformation was used to normalize the dependent variable. Significant relationships are in bold. The final model utilized 1971 observations collected from 1606 known individual whales and produced an $\mathrm{R}^{2}$ coefficient based on likelihood ratio of 0.137

\begin{tabular}{|c|c|c|c|c|}
\hline Parameter & & $\beta$ & p-value & $95 \% \mathrm{CI}$ \\
\hline Intercept & & 4.63 & 0.000 & $4.56,4.69$ \\
\hline \multirow[t]{2}{*}{ Season } & Autumn $^{\mathrm{a}}$ & & & \\
\hline & Summer & 0.05 & 0.018 & $0.01,0.09$ \\
\hline \multirow[t]{5}{*}{ Depth } & $<10 \mathrm{~m}^{\mathrm{a}}$ & & & \\
\hline & $10-19 \mathrm{~m}$ & 0.10 & 0.004 & $0.03,0.17$ \\
\hline & $20-49 \mathrm{~m}$ & 0.12 & 0.000 & $0.06,0.19$ \\
\hline & 50-199 m & 0.11 & 0.012 & $0.03,0.19$ \\
\hline & $>200 \mathrm{~m}$ & 0.14 & 0.022 & $0.02,0.26$ \\
\hline \multirow[t]{2}{*}{ Seismic } & Undisturbed $^{\mathrm{a}}$ & & & \\
\hline & Present & 0.37 & 0.000 & $0.20,0.54$ \\
\hline \multirow[t]{2}{*}{ Reproductive status } & Non-calf ${ }^{a}$ & & & \\
\hline & Mother & 0.19 & 0.000 & $0.11,0.27$ \\
\hline \multirow[t]{3}{*}{ Activity } & Forage $^{a}$ & & & \\
\hline & Travel & 0.19 & 0.000 & $0.15,0.24$ \\
\hline & Social & 0.01 & 0.512 & $-0.03,0.05$ \\
\hline \multirow[t]{3}{*}{ Group size } & $1-2^{\mathrm{a}}$ & & & \\
\hline & $2-3$ & 0.09 & 0.000 & $0.06,0.13$ \\
\hline & $>4$ & 0.01 & 0.883 & $-0.07,0.08$ \\
\hline \multirow[t]{2}{*}{ Aerial } & None $^{a}$ & & & \\
\hline & Present & 0.08 & 0.009 & $0.02,0.15$ \\
\hline \multicolumn{5}{|l|}{ Seismic $\times$ Autumn $^{a}$} \\
\hline & Seismic $\times$ Summer & -0.19 & 0.000 & $-0.27,-0.11$ \\
\hline \multicolumn{5}{|l|}{ Seismic $x<10 \mathrm{~m}^{\mathrm{a}}$} \\
\hline & Seismic $\times 10-19 \mathrm{~m}$ & -0.32 & 0.000 & $-0.49,-0.15$ \\
\hline & Seismic $\times 20-49 \mathrm{~m}$ & -0.31 & 0.000 & $-0.47,-0.14$ \\
\hline & Seismic $\times$ 50-199 m & -0.06 & 0.541 & $-0.25,0.13$ \\
\hline & Seismic $x>200 \mathrm{~m}$ & -0.25 & 0.018 & $-0.46,-0.04$ \\
\hline \multicolumn{5}{|l|}{ Seismic $\times$ Forage $^{\mathrm{a}}$} \\
\hline & Seismic $\times$ Travel & -0.15 & 0.013 & $-0.26,-0.03$ \\
\hline & Seismic $\times$ Social & 0.02 & 0.573 & $-0.06,0.10$ \\
\hline \multicolumn{5}{|l|}{ Seismic $\times$ No aerial ${ }^{a}$} \\
\hline & Seismic $\times$ Aerial & 0.32 & 0.006 & $0.09,0.54$ \\
\hline
\end{tabular}

any category of reproductive status, season, or whale activity (Tables $4 \mathrm{a}, 4 \mathrm{~b}, \& 4 \mathrm{c}$ ).

Similarly, the presence of seismic operations had no apparent effect on the proportion of time that mothers, non-calves, or calves spent at the surface (Fig. 3, Table 4a). Though not significantly different, it should be noted that the proportion of time that non-calf whales spent at the surface during autumn was $17.7 \%$ in presumably undisturbed conditions but only $12.4 \%$ during seismic operations (Table $4 \mathrm{~b}$ ).

Further investigation of the effects of seismic operations on blow rates and the proportion of time that bowheads spent at the surface (with allowance for other variables) was precluded by the available sample sizes.

\section{Sensitivity analysis}

Despite some uncertainty about the effects of some explanatory variables on bowhead SRD behavior, the overall results of the retrospective sensitivity analysis confirmed that the presence of seismic operations did affect bowhead SRD behaviors - and sensitivity analyses (see below) suggested that the selected final models were reasonably robust. Furthermore, the effects of exposure to seismic operations sometimes varied according to whale reproductive status, season, and whale activity.

The sensitivity analysis confirmed the importance of a number of explanatory variables in the model for each of the 4 SRD variables despite the sequential removal of data (Tables S1a to S1d in the Supplement at www.intres.com/articles/suppl/n021p143_supp. pdf). Most notably, the apparent effect of seismic operations as a predictor of SRD behavior remained evident for each SRD behavior, either on its own or when interacting with other variables. For example, the presence of seismic operations was identified as important in all models for dive duration that included data from $\geq 3$ years (Table S1d). Other important effects corroborated by the sensitivity analysis included those of season and movement speed as explanatory variables for the number of blows per surfacing and duration of surfacing, while water depth had a nominally significant effect (Tables S1a \& S1c). However, the apparent effect of depth on dive duration varied greatly with the removal of data, and depth was included as a nominally significant factor in only 5 of 9 models for dive duration.

Small and unequal sample sizes, a result of compiling behavior data from multiple studies, may also have contributed to the observed differences among LME models. This was evident from the sensitivity analysis for surface duration (Table S1c). There, the sequential removal of data and refitting of models led to an increasing apparent significance of season, which in turn reflected the sample sizes available from summer and autumn. All the behavior data collected after 1985 were 
Table 5c. Linear mixed effects model for the mean surface duration for bowhead whales. A square-root transformation was used to normalize the dependent variable. Significant relationships are in bold. The final model utilized 957 observations collected from 725 known individual whales and produced an $\mathrm{R}^{2}$ coefficient based on likelihood ratio of 0.239

\begin{tabular}{|c|c|c|c|c|}
\hline Parameter & & $\beta$ & $\mathrm{p}$-value & $95 \% \mathrm{CI}$ \\
\hline Intercept & & 9.67 & 0.000 & $8.63,10.71$ \\
\hline \multirow[t]{2}{*}{ Season } & Autumn $^{\mathrm{a}}$ & & & \\
\hline & Summer & -0.55 & 0.018 & $-1.01,-0.10$ \\
\hline \multirow[t]{5}{*}{ Depth } & $<10 \mathrm{~m}^{\mathrm{a}}$ & & & \\
\hline & $10-19 \mathrm{~m}$ & -0.05 & 0.904 & $-0.82,0.73$ \\
\hline & $20-49 \mathrm{~m}$ & 0.16 & 0.681 & $-0.60,0.92$ \\
\hline & $50-199 \mathrm{~m}$ & 1.10 & 0.023 & $0.16,2.05$ \\
\hline & $>200 \mathrm{~m}$ & 2.31 & 0.000 & $1.15,3.47$ \\
\hline \multirow[t]{2}{*}{ Ice \% } & $\leq 5 \%{ }^{\mathrm{a}}$ & & & \\
\hline & $>5 \%$ & 0.94 & 0.002 & $0.34,1.55$ \\
\hline \multirow{2}{*}{ Seismic } & Undisturbed $^{\mathrm{a}}$ & & & \\
\hline & Present & 1.67 & 0.031 & $0.15,3.20$ \\
\hline \multirow[t]{2}{*}{ Reproductive status } & Non-calf ${ }^{a}$ & & & \\
\hline & Mother & 1.50 & 0.004 & $0.49,2.50$ \\
\hline \multirow[t]{3}{*}{ Activity } & Forage $^{a}$ & & & \\
\hline & Travel & 0.69 & 0.034 & $0.05,1.32$ \\
\hline & Social & 0.29 & 0.276 & $-0.23,0.81$ \\
\hline \multirow[t]{4}{*}{ Motion } & None $^{\mathrm{a}}$ & & & \\
\hline & Fast & -2.79 & 0.000 & $-3.79,-1.81$ \\
\hline & Moderate & -2.10 & 0.000 & $-2.64,-1.56$ \\
\hline & Slow & -1.19 & 0.000 & $-1.66,-0.72$ \\
\hline Log(whales in 1 km) & & -0.15 & 0.449 & $-0.55,0.25$ \\
\hline \multirow[t]{3}{*}{ Seismic $\times$ Forage $^{\mathrm{a}}$} & & & & \\
\hline & Seismic $\times$ Travel & -2.35 & 0.000 & $-3.59,-1.10$ \\
\hline & Seismic $\times$ Social & -0.19 & 0.715 & $-1.22,0.83$ \\
\hline \multicolumn{2}{|c|}{ Seismic $\times \log ($ whales in $1 \mathrm{~km})$} & -0.88 & 0.032 & $-1.68,-0.08$ \\
\hline 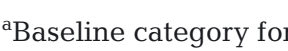 & this variable & & & \\
\hline
\end{tabular}

from autumn, resulting in a seasonal unbalance in the data.

In summary, the presence of seismic operations generally resulted in shorter surfacings. This change was particularly apparent for non-calf whales engaged in travel and socializing. Our mixed model analysis also established that the presence of seismic affected the dive times of bowhead whales, but the effect depended on the season, whale activity state, and numbers of whales nearby.

\section{DISCUSSION}

Exposure to seismic operations resulted in subtle changes to bowhead whale surfacing, respiration, and dive behaviors. The observed behavioral responses corresponded with the skittish behaviors reported by subsistence whalers (Jolles 1995) as well as anti-predation behaviors observed in other airbreathing aquatic foragers (Dunphy-Daly et al. 2010, Wirsing et al. 2011). The effects of such industry oper- ations on bowhead behaviors have implications for the detectability of bowhead whales during aerial surveys, thereby influencing the ability to adequately assess the effects of industry on bowhead whale distribution. Allowance for these effects on detectability will lead to improvements in the management of industry operations in the Alaskan Arctic.

\section{Effects of seismic operations on bowhead whale behavior}

LME models proved to be a more powerful tool than the univariate and stepwise multiple regression analyses used in earlier studies to assess the effects of seismic operations on bowhead SRD behavior in the Beaufort Sea. The LME models confirmed that seismic operations significantly affected bowhead SRD behavior and showed that the degree of behavioral change depended on factors such as season, activity states, and the number of whales within $1 \mathrm{~km}$ of the affected whale. Although some of the earliest studies detected subtle differences in dive-cycle behaviors in the presence vs. absence of seismic sounds (e.g. Richardson et al. 1986, 1995b, Ljungblad et al. 1988), they did not attempt to allow for the confounding effects of other key variables or to account for repeated observations of individual whales.

Pooling data from multiple studies enabled us to investigate the seasonal effects of seismic operations and other factors on bowhead behaviors. The results suggest that non-calf whales had stronger reactions to seismic operations in autumn than in summer. Similarly, seismic operations had a greater effect on SRD behavior while non-calf whales were traveling than while whales were engaged in feeding or socializing activities (as indicated by some significant interactions between seismic and whale activity in the behavior models).

During the westward autumn migration through the Alaskan Beaufort Sea, the primary activity is traveling, although bowheads intersperse periods of traveling with feeding (Ljungblad et al. 1986, Richardson \& Thomson 2002, Koski et al. 2009). Tagging studies have confirmed that the residence times of 
Table 5d. Linear mixed effects model for the mean dive duration for bowhead whales. A log transformation was used to normalize the dependent variable. Significant relationships are in bold. The final model utilized 455 observations collected from 189 known individual whales and produced an $\mathrm{R}^{2}$ coefficient based on likelihood ratio of 0.386

\begin{tabular}{|c|c|c|c|c|}
\hline Parameter & & $\beta$ & $\mathrm{p}$-value & $95 \% \mathrm{CI}$ \\
\hline Intercept & & 6.03 & 0.000 & $5.57,6.49$ \\
\hline \multirow{2}{*}{ Season } & Autumn $^{\mathrm{a}}$ & & & \\
\hline & Summer & -0.07 & 0.669 & $-0.37,0.24$ \\
\hline \multirow[t]{5}{*}{ Depth } & $<10 \mathrm{~m}^{\mathrm{a}}$ & & & \\
\hline & $10-19 \mathrm{~m}$ & 0.06 & 0.795 & $-0.38,0.50$ \\
\hline & $20-49 \mathrm{~m}$ & 0.38 & 0.072 & $-0.03,0.80$ \\
\hline & $50-199 \mathrm{~m}$ & 0.34 & 0.172 & $-0.15,0.84$ \\
\hline & $>200 \mathrm{~m}$ & 0.63 & 0.022 & $0.09,1.18$ \\
\hline \multirow[t]{2}{*}{ Ice \% } & $\leq 5 \%{ }^{\mathrm{a}}$ & & & \\
\hline & $>5 \%$ & 0.30 & 0.034 & $0.02,0.58$ \\
\hline \multirow[t]{2}{*}{ Seismic } & Undisturbed $^{\mathrm{a}}$ & & & \\
\hline & Present & 1.08 & 0.002 & $0.41,1.75$ \\
\hline \multirow[t]{2}{*}{ Reproductive status } & Non-calf ${ }^{a}$ & & & \\
\hline & Mother & 0.50 & 0.007 & $0.14,0.86$ \\
\hline \multirow[t]{3}{*}{ Group size } & $1-2^{\mathrm{a}}$ & & & \\
\hline & $2-3$ & -0.25 & 0.011 & $-0.44,-0.06$ \\
\hline & $\geq 4$ & -0.53 & 0.192 & $-1.33,0.27$ \\
\hline \multirow[t]{3}{*}{ Activity } & Forage $^{\mathrm{a}}$ & & & \\
\hline & Travel & -0.02 & 0.908 & $-0.35,0.32$ \\
\hline & Social & -0.34 & 0.052 & $-0.68,0.00$ \\
\hline $\log ($ whales in $1 \mathrm{~km})$ & & -0.24 & 0.014 & $-0.44,-0.05$ \\
\hline \multicolumn{5}{|l|}{ Seismic $\times$ Autumn ${ }^{\mathrm{a}}$} \\
\hline \multirow[t]{3}{*}{ Seismic $\times$ Forage ${ }^{a}$} & 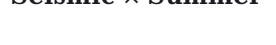 & & & 10078000 \\
\hline & Seismic $\times$ Travel & -0.83 & 0.019 & $-1.52,-0.14$ \\
\hline & Seismic $\times$ Social & 0.77 & 0.016 & $0.15,1.40$ \\
\hline \multicolumn{2}{|c|}{ Seismic $\times \log ($ whales in $1 \mathrm{~km})$} & -0.50 & 0.011 & $-0.88,-0.12$ \\
\hline${ }^{\text {a} B a s e l i n e ~ c a t e g o r y ~ f o ~}$ & r this variable & & & \\
\hline
\end{tabular}

most bowhead whales in the Alaskan Beaufort Sea during the autumn are less than a few days (Quakenbush et al. 2010, ADFG 2012), indicating that feeding in that area and season is likely opportunistic. Our findings suggest that traveling whales exposed to seismic operations spent the least time at the surface and had markedly reduced numbers of exhalations per surfacing. Also, the behavior of non-calf whales was more notably affected by seismic operations during autumn migration than during summer, when feeding and socializing are key activities. However, our results should be interpreted with caution due to the inadequate sample sizes for traveling non-calf whales during the summer, which prevented us from comparing the behavior of traveling whales exposed to seismic operations in summer and autumn.

Our results lend support to the hypothesis that feeding and socializing whales are more tolerant of seismic operations than are traveling whales. Feeding bowhead whales exposed to seismic operations may vary their SRD behaviors (Richardson et al.
1986) but often stayed near seismic activities (Richardson et al. 1986, Miller et al. 2005, Koski et al. 2009). This was in sharp contrast to migrating whales that appeared to avoid seismic operations by distances of $20-30 \mathrm{~km}$ (Richardson et al. 1999, Manly et al. 2007). Gray whales Eschrichtius robustus (Gailey et al. 2007, Yazvenko et al. 2007) and sperm whales Physeter macrocephalus (Madsen et al. 2002, Miller et al. 2009) have also been observed foraging near seismic operations, but there is less information for those species about their relative response to seismic during foraging vs. migration. Our findings further suggest that traveling bowhead whales may not avoid ensonified areas to quite the extent reported in previous aerial-studies (e.g. Richardson et al. 1986, Manly et al. 2007). Earlier studies may have slightly overestimated the degree of avoidance because they did not recognize or allow for the fact that bowheads exposed to seismic operations may be less available for detection at the surface due to changes in SRD behavior.

Cetaceans commonly alter their SRD behaviors in response to human activities. Navy sonar, aircraft, ship traffic, ice breaking, and marine construction have all led to observable behavioral changes in cetaceans (Richardson et al. 1995a, Southall et al. 2007). For example, low-frequency sounds led to longer dives in humpback whales Megaptera novaeangliae (Frankel \& Clark 1998), while harbor porpoises Phocoena phocoena varied their surfacing patterns by moving away or increasing dive times in response to imaging sonar systems (Hastie 2012). Gray whales sometimes avoid airgun operations (e.g. Malme et al. 1984) and also change their movement patterns and dive durations as exposure to seismic sound increases (Gailey et al. 2007). However, cetaceans may also show little if any behavioral response to a human activity in some circumstances, as reported for humpback whales exposed to blasting (Todd et al. 1996) or sperm whales exposed to distant explosions (Madsen \& Møhl 2000). The variation in behavioral responses of cetaceans to human activities suggests that responses are context-dependent and vary with the circumstances and activity of the animals as well as 
the level of perceived threat (Richardson et al. 1995a, Ellison et al. 2012).

The behavioral responses of bowhead whales to seismic sounds are similar to anti-predator or antithreat responses observed in other air-breathing aquatic foragers (Frid et al. 2007, Dunphy-Daly et al. 2010, Wirsing et al. 2011). The behavioral changes exhibited by bowhead whales in the presence of human activities are sometimes subtle and can result in the whales apparently becoming more secretive. Similar behavioral reactions have been recognized by Iñupiat subsistence whalers. Whaling captains report that bowheads are easily startled by sudden noises, resulting in the whales surfacing less and moving further out to sea (Jolles 1995). Gray whales have also been observed to adopt a distinctive lowprofile breathing technique, known as snorkeling, when faced with the threat of predation from killer whales Orcinus orca (Reeves et al. 2006, Ford \& Reeves 2008). These behaviors presumably reduce whale susceptibility to potential subsurface predators, such as the killer whale, that pose a threat to diving animals at the surface by restricting fleeing movement laterally or downwards (Heithaus \& Frid 2003). Numbers of bowhead whale calls have also been reported to be lower when exposed to seismic sounds (Greene et al. 1999, Blackwell et al. 2013). Reduced calling behavior is hypothesized to be related to secretiveness, particularly as silent whales are likely harder for killer whales to detect. However, lower rates of call detection in the presence of seismic sounds are presumably also partly related to documented avoidance reactions (i.e. the presence of fewer whales in the area of active seismic operations).

\section{Implications for management}

Aerial surveys are often used to estimate distributions and densities of animals near industrial activities, such as a seismic operation. However, a whale is only available for visual detection when it is at or very near the surface. Any changes in behavior that result in whales spending less time at the surface during a typical SRD cycle, or being less conspicuous when at the surface, reduce an observer's ability to sight them. Not accounting for these behavioral changes will result in underestimates of numbers of animals present.

Results from our study can be incorporated into calculations of availability correction factors that account for the reduced probability of detecting an animal at the surface (Buckland et al. 2001). These cor- rection factors will be particularly useful when incorporated into the analysis of sightings data collected during aerial monitoring of industry activities during the autumn migration of bowhead whales. Understanding and quantifying the effects of seismic operations on bowhead SRD behaviors will result in more accurate density assessments from sighting surveys and better estimates of the numbers of whales that were likely exposed to a seismic operation. It should also help provide more accurate estimates of the probability of avoidance around seismic operations.

\section{Study limitations}

Our analyses expanded on previous studies of seismic effects on SRD behavior by attempting to account for repeated observations of individual whales and for the various factors and interactions of factors that influence SRD variables. Similar mixed model analyses have been successfully applied in behavioral response studies of humpback whales (Dunlop et al. 2013). However, these improved analyses of the effects of seismic operations on bowhead whale SRD behavior remain subject to some limitations.

A key caveat to our analyses centers on the issue of statistical independence. Mann-Whitney $U$-tests and Kruskal-Wallis tests assume independent samples. Individual whales were often observed more than once during a behavioral observation session, leading to repeated measures of SRD behaviors from some individual whales. We partly addressed this by acknowledging that the calculated significance levels were nominal and by giving little emphasis to differences whose nominal significance levels had $q>$ 0.01 . We also applied mixed effects models to these data, with individually identified whales (when recognized) treated as a random factor. However, it was often impossible to know whether a whale observed for one or more surfacings was involved in a previously observed surfacing. We treated the observations in such cases as coming from separate whales. Thus, the results of our mixed-effects models may overstate statistical significance to some extent. Future analyses of such data could consider using the behavioral observation session (rather than the assumed individual whale) as the random effect, which would ensure that the assumption of independence is robust. This approach would further help address any synchronicity in the behaviors of whales observed in close proximity during a single behavioral observation session. However, these analyses were outside the scope of our study. 
Most of the behavioral observations near seismic operations were collected in an opportunistic fashion with little control over where and when observations of whales exposed to seismic operations occurred and with only approximate information on the highly variable seismic sound levels to which the animals were exposed (Richardson et al. 1986, Koski \& Johnson 1987). As a result, data were not collected under all of the desired situations, such as for traveling whales in summer. Also, it was not possible to include received sound level as a probable explanatory variable in our statistical tests, and that limitation presumably reduced their statistical power. The variety of conditions (including the range of sound exposure levels) over which the observations were collected probably led to increased variability in SRD behaviors, and some of this variation was detected in the sensitivity analysis.

To maximize the data available for analysis, we chose to categorize variables such as water depth and group size (rather than treating them as continuous or nearly so). This may have led to a loss of statistical power. However, the depth category was selected as a significant variable in the LME models for all 4 SRD variables, and there was an apparent progression in $\beta$ coefficients with increasing depth for 3 of 4 SRD variables - the number of blows per surfacing, surface duration, and dive duration (Tables 5a, 5c \& 5d). This indicates the importance of depth in explaining the variation in each SRD behavior. Our application of LME models allowed us to address some of the variability in the data. Although the selected models explained $<40 \%$ of the variation in the data, the results provided insights into the effect of seismic sound that have not been achieved previously.

Variability in the presence of ice and the distribution and availability of prey affect the distribution of whales and thus the sites of behavioral observations. Such variability resulted in small and unequal sample sizes under different conditions used for the present study. We were also unable to quantify or include some factors in our models, such as prey abundance, which is likely an important determinant of distribution, activity state, and effects of seismic operations on the whales. Failure to include these variables may have contributed to the limited predictive capacity of the models. Behavioral data collected in the presence of seismic operations were also limited. All systematic aerial observations of bowhead behavior in the presence of seismic operations were obtained in the early to mid-1980s (e.g. Richardson et al. 1986, Koski \& Johnson 1987). It was not possible to collect such data during more recent studies of bowheads near seismic operations. The number of observations of dive duration (and thus proportion of time at surface) in the presence of seismic operations was particularly small. That limited our investigations of the effects of season and whale activities on those parameters to non-calf whales only and precluded multivariate (LME) analysis of the key 'proportion of time at the surface' variable. But more importantly, the small samples and frequent lack of specific sound-exposure information meant that we were unable to incorporate distance to the sound source or received level of sound into our analyses. Thus, we were restricted to a relatively simple assessment based on the presence or absence of seismic sounds.

The available data confirm that the presence of seismic operations led in some circumstances to changes in the SRD behavior of bowhead whales. The new analyses also show that the responses to seismic operations varied with season and some activity states of the whales. Although the biological consequences are unknown, subtle changes to SRD behaviors are likely to affect the detectability of bowhead whales by aerial observers. Quantitative data on SRD behavior in relation to context (including the presence/absence of seismic sound) can improve understanding of the effects of seismic operations on bowhead distribution and subsistence activities in the Beaufort Sea. Similar principles likely apply to vessel-based surveys and to other seasons, species, and regions - although our data are specific to aerial observations of bowhead whales in the Beaufort Sea in summer and autumn.

Acknowledgements. We thank the LGL observers, aircraft companies, and pilots who assisted in collecting the behavioral data over the many years as well as those companies, the US Bureau of Land Management, and the former US Minerals Management Service (MMS) that funded the many studies that resulted in the large behavioral database available to us today. The analyses were carried out with the support of an NSERC-IPS Scholarship, awarded to F.C.R., along with additional support from LGL Ltd., environmental research associates. We also thank R. Joy and Dr. J. Brandon for their statistical advice, A. Thomas for production of the map, and U. Gorter for the illustration of the bowhead whale SRD behaviors. Finally, many thanks to the 3 anonymous reviewers whose comments and suggestions strengthened the paper.

\section{LITERATURE CITED}

ADFG (2012) Satellite tracking of Western Arctic bowhead whales. Alaska Dept of Fish and Game, Juneau, AK. Available at www.adfg.alaska.gov/index.cfm?adfg= marinemammalprogram.bowhead (accessed 9 Aug 2012) 
Beale CM, Monaghan P (2004) Behavioural responses to human disturbance: a matter of choice? Anim Behav 68: 1065-1069

Blackwell SB, Nations CS, McDonald TL, Greene CR Jr, Thode AM, Guerra M, Macrander AM (2013) Effects of airgun sounds on bowhead whale calling rates in the Alaskan Beaufort Sea. Mar Mamm Sci (in press) doi: 10.1111/mms.12001

Buckland ST, Anderson DR, Burnham KP, Laake JL, Borchers DL, Thomas L (2001) Introduction to distance sampling: estimating abundance of biological populations. Oxford University Press, Oxford

Canty A, Ripley B (2011) boot: bootstrap R (S-Plus) functions. R package v. 1.3-1. Available at: http://cran.at.r-project. org/web/packages/boot/index.html

Davis RA, Koski WR, Richardson WJ, Evans CR, Alliston WG (1982) Distribution, numbers and productivity of the Western Arctic stock of bowhead whales in the eastern Beaufort Sea and Amundsen Gulf, summer 1981. Report from LGL Ltd., Toronto, ON. Summarized as SC/34/ PS20, Int Whal Comm, Cambridge

Diggle PJ, Heagerty P, Liang KY, Zeger SL (2002) Analysis of longitudinal data. Oxford University Press, Oxford

$>$ Dorsey EM, Richardson WJ, Würsig B (1989) Factors affecting surfacing, respiration, and dive behaviour of bowhead whales, Balaena mysticetus, summering in the Beaufort Sea. Can J Zool 67:1801-1815

> Dunlop RA, Noad MJ, Cato DH, Kniest E, Miller PJO, Smith JN, Stokes MD (2013) Multivariate analysis of behavioural response experiments in humpback whales (Megaptera novaeangliae). J Exp Biol 216:759-770

> Dunphy-Daly MM, Heithaus MR, Wirsing AJ, Mardon JSF, Burkholder DA (2010) Predation risk influences the diving behavior of a marine mesopredator. Open Ecol J 3: 8-15

- Ellison WT, Southall BL, Clark CW, Frankel AS (2012) A new context-based approach to assess marine mammal behavioral responses to anthropogenic sounds. Conserv Biol 26:21-28

Faul F, Erdfelder E, Lang A, Buchner A (2007) G*Power 3: a flexible statistical power analysis program for the social, behavioral, and biomedical sciences. Behav Res Methods 39:175-191

Ford JKB, Reeves RR (2008) Fight or flight: antipredator strategies of baleen whales. Mammal Rev 38:50-86

- Frankel AS, Clark CW (1998) Results of low-frequency playback of M-sequence noise to humpback whales, Megaptera novaeangliae, in Hawaìi. Can J Zool 76: 521-535

Frid A, Heithaus MR, Dill LM (2007) Dangerous dive cycles and the proverbial ostrich. Oikos 116:893-902

Gailey G, Würsig B, McDonald TL (2007) Abundance, behavior, and movement patterns of western gray whales in relation to a 3-D seismic survey, Northeast Sakhalin Island, Russia. Environ Monit Assess 134:75-91

> Greene CR Jr, Richardson WJ (1988) Characteristics of marine seismic survey sounds in the Beaufort Sea. J Acoust Soc Am 83:2246-2254

Greene CR Jr, Altman NS, Richardson WJ (1999) The influence of seismic survey sounds on bowhead whale calling rates. J Acoust Soc Am 106:2280

Hastie GD (2012) Tracking marine mammals around marine renewable energy devices using active sonar. Rep SMRUL-DEC-2012-002 SMRU Ltd., St. Andrews. Available at: http://mhk.pnnl.gov/wiki/images/a/a8/SMRU_2012.pdf
Heithaus MR, Frid A (2003) Optimal diving under the risk of predation. J Theor Biol 223:79-92

Johnson DH (1999) The insignificance of statistical significance testing. J Wildl Manag 63:763-772

Jolles CZ (ed) (1995) Speaking of whaling: a transcript of the Alaskan Eskimo Whaling Commission panel presentation on native whaling. In: McCartney AP (ed) Hunting the largest animals, native whaling in the Western Arctic and Subarctic. Studies in Whaling No. 3, Circumpolar Institute, University of Alberta, Edmonton, p 315-337

Koski WR, Johnson SR (1987) Responses of bowhead whales to an offshore drilling operation in the Alaskan Beaufort Sea, Autumn 1986: behavioral studies and aerial photogrammetry. LGL Ltd., King City, ON

Koski WR, Funk DW, Ireland DS, Lyons C, Christie K, Macrander AM, Blackwell SB (2009) An update on feeding by bowhead whales near an offshore seismic survey in the central Beaufort Sea. SC/61/BRG3, International Whaling Commission, Available at: http://iwc.int/index. php?cID $=1780 \&$ cType $=$ document

Kramer M (2005) R ${ }^{2}$ statistics for mixed models. In: Proc Conf Applied Statistics in Agriculture, April 2005. Kansas State University, Manhattan, KS, p 148-160

Landino SW, Treacy SD, Zerwick SA, Dunlap JB (1994) A large aggregation of bowhead whales (Balaena mysticetus) feeding near Point Barrow, Alaska, in late October 1992. Arctic 47:232-235

Liu H, Zheng Y, Shen J (2008) Goodness-of-fit measures of $\mathrm{R}^{2}$ for repeated measures mixed effect models. J Appl Stat 35:1081-1092

Ljungblad DK, Moore SE, Clarke JT (1986) Assessment of bowhead whale (Balaena mysticetus) feeding patterns in the Alaskan Beaufort and northeastern Chukchi Seas via aerial surveys, fall 1979-84. Rep Int Whal Comm 36: 265-272

Ljungblad DK, Würsig B, Swartz SL, Keene JM (1988) Observations on the behavioral responses of bowhead whales (Balaena mysticetus) to active geophysical vessels in the Alaskan Beaufort Sea. Arctic 41:183-194

- Madsen PT, Møhl B (2000) Sperm whales (Physeter catodon L. 1758) do not react to sounds from detonators. J Acoust Soc Am 107:668-671

Madsen PT, Møhl B, Nielsen BK, Wahlberg M (2002) Male sperm whale behaviour during exposures to distant seismic survey pluses. Aquat Mamm 28:231-240

Maj A (2011) lmmfit: goodness-of-fit-measures for linear mixed models with one-level-grouping. R package, v. 1.0. Available at: http://cran.r-project.org/web/packages/ lmmfit/index.html

Malme CI, Miles PR, Clark CW, Tyack P, Bird JE (1984) Investigations of the potential effects of underwater noise from petroleum industry activities on migrating gray whale behavior. Phase II: January 1984 migration. Bolt Beranek and Newman Inc., Cambridge, MA. Available at www.boem.gov/BOEM-Newsroom/Library/ Publications/1983/rpt5586.aspx

Manly BFJ, Moulton VD, Elliott RE, Miller GW, Richardson WJ (2007) Analysis of covariance of fall migrations of bowhead whales in relation to human activities and environmental factors, Alaskan Beaufort Sea: Phase I, 1996-1998. OCS Study 2005-033; LGL Rep TA2799-3. LGL Ltd., King City, ON, and WEST Inc., Cheyenne, WY. Available at www.boem.gov/BOEM-Newsroom/Library/ Publications/2005/2005-033.aspx 
Miller GW, Moulton VD, Davis RA, Holst M, Millman P, MacGillivray A, Hannay D (2005) Monitoring seismic effects on marine mammals - southeastern Beaufort Sea, 2001-2002. In: Armsworthy SL, Cranford PJ, Lee K (eds) Offshore oil and gas environmental effects monitoring/approaches and technologies. Battelle Press, Columbus, OH, p 511-542

Miller PJO, Johnson MP, Madsen PT, Biassoni N, Quero M, Tyack PL (2009) Using at-sea experiments to study the effects of airguns on the foraging behavior of sperm whales in the Gulf of Mexico. Deep-Sea Res I 56: 1168-1181

Moore SE, Reeves RR (1993) Distribution and movement. In: Burns JJ, Montague JJ, Cowles CJ (eds) The bowhead whale. Spec Pub No. 2, The Society for Marine Mammalogy, Allen Press, Lawrence, KS, p 313-386

Moore SE, Clarke JT, Ljungblad DK (1989) Bowhead whale (Balaena mysticetus) spatial and temporal distribution in the central Beaufort Sea during late summer and early fall 1979-1986. Rep Int Whal Comm 39:283-290

Moore SE, George JC, Sheffield G, Bacon J, Ashjian CJ (2010) Bowhead whale distribution and feeding near Barrow, Alaska, in late summer 2005-06. Arctic 63: 195-205

Moore SE, Reeves RR, Southall BL, Ragen TJ, Suydam RS, Clark CW (2012) A new framework for assessing the effects of anthropogenic sound on marine mammals in a rapidly changing Arctic. BioScience 62:289-295

Patenaude NJ, Richardson WJ, Smultea MA, Koski WR, Miller GW, Würsig B, Greene CR Jr (2002) Aircraft sound and disturbance to bowhead and beluga whales during spring migration in the Alaskan Beaufort Sea. Mar Mamm Sci 18:309-335

Pinheiro J, Bates D, DebRoy S, Sarkar D, R Development Core Team (2011) nlme: linear and nonlinear mixed effects models. R package v. 3.1-101. Available at: http:// cran.r-project.org/web/packages/nlme/index.html

Quakenbush LT, Citta JJ, George JC, Small RJ, HeideJørgensen MP (2010) Fall and winter movements of bowhead whales (Balaena mysticetus) in the Chukchi Sea and within a potential petroleum development area. Arctic 63:289-307

Reeves RR, Berger J, Clapham PJ (2006) Killer whales as predators of large baleen whales and sperm whales. In: Estes JA, DeMaster DP, Doak DF, Williams TM, Brownell RL Jr (eds) Whales, whaling, and ocean ecosystems. University of California Press, Berkeley, CA, p 174-187

Reeves R, Rosa C, George JC, Sheffield G, Moore M (2012) Implications of Arctic industrial growth and strategies to mitigate future vessel and fishing gear impacts on bowhead whales. Mar Policy 36:454-462

Richardson WJ, Malme CI (1993) Man-made noise and behavioral responses. In: Burns JJ, Montague JJ, Cowles CJ (eds) The bowhead whale. Spec Pub No. 2, The Society for Marine Mammalogy, Allen Press, Lawrence, KS, p $631-700$

Richardson WJ, Thomson DH (eds) (2002) Bowhead whale feeding in the eastern Alaskan Beaufort Sea: update of scientific and traditional information. OCS study MMS 2002-012; LGL Rep TA2196-7, Vols 1 \& 2. LGL Ltd.,
King City, ON. Available at www.boem.gov/BOEMNewsroom/Library/Publications/2002/2002-012.aspx

> Richardson WJ, Fraker MA, Würsig B, Wells RS (1985) Behaviour of bowhead whales Balaena mysticetus summering in the Beaufort Sea: reactions to industrial activities. Biol Conserv 32:195-230

> Richardson WJ, Würsig B, Greene CR Jr (1986) Reactions of bowhead whales, Balaena mysticetus, to seismic exploration in the Canadian Beaufort Sea. J Acoust Soc Am 79: $1117-1128$

Richardson WJ, Davis RA, Evans CR, Ljungblad DK, Norton $P$ (1987) Summer distribution of bowhead whales, Balaena mysticetus, relative to oil industry activities in the Canadian Beaufort Sea, 1980-84. Arctic 40:93-104

Richardson WJ, Greene CR Jr, Malme CI, Thomson DH (1995a) Marine mammals and noise. Academic Press, San Diego, CA

Richardson WJ, Finley KJ, Miller GW, Davis RA, Koski WR (1995b) Feeding, social and migration behavior of bowhead whales, Balaena mysticetus, in Baffin Bay vs. the Beaufort Sea - regions with different amounts of human activity. Mar Mamm Sci 11:1-45

> Richardson WJ, Miller GW, Greene CR Jr (1999) Displacement of migrating bowhead whales by sounds from seismic surveys in shallow waters of the Beaufort Sea. J Acoust Soc Am 106:2281

Southall BL, Bowles AE, Ellison WT, Finneran JJ and others (2007) Marine mammal noise exposure criteria: initial scientific recommendations. Aquat Mamm 33:411-522

Storey JD (2002) A direct approach to false discovery rates. J R Stat Soc B 64:479-498

Todd S, Stevick P, Lien J, Marques F, Ketten D (1996) Behavioural effects of exposure to underwater explosions in humpback whales (Megaptera novaeangliae). Can J Zool 74:1661-1672

> Vonesh EF, Chinchilli VM, Pu K (1996) Goodness-of-fit in generalized nonlinear mixed-effects models. Biometrics 52:572-587

Wirsing AJ, Heithaus MR, Dill LM (2011) Predator-induced modifications to diving behavior vary with foraging mode. Oikos 120:1005-1012

> Würsig B, Dorsey EM, Fraker MA, Payne RS, Richardson WJ, Wells RS (1984) Behavior of bowhead whales, Balaena mysticetus, summering in the Beaufort Sea: surfacing, respiration, and dive characteristics. Can J Zool 62: 1910-1921

Würsig B, Dorsey EM, Fraker MA, Payne RS, Richardson WJ (1985) Behavior of bowhead whales, Balaena mysticetus, summering in the Beaufort Sea: a description. Fish Bull 83:357-377

> Yazvenko SB, McDonald TL, Blokhin SA, Johnson SR and others (2007) Feeding of western gray whales during a seismic survey near Sakhalin Island, Russia. Environ Monit Assess 134:93-106

Zuur AF, Ieno EN, Walker NJ, Saveliev AA, Smith GM (2009) Mixed effects models and extensions in ecology with R. Springer, New York, NY

Zuur AF, Ieno EN, Elphick CS (2010) A protocol for data exploration to avoid common statistical problems. Methods Ecol Evol 1:3-14
Editorial responsibility: Robert Harcourt, Sydney, New South Wales, Australia
Submitted: November 12, 2012; Accepted: May 5, 2013

Proofs received from author(s): July 20, 2013 